\title{
Otimismo e trabalho!
}

A depressão e os males causados pelo estado de ânimo das pessoas são os temas que mais afligem a saúde do povo brasileiro. Isso foi o que constatou uma pesquisa recente realizada pela Fundação Oswaldo Cruz, a pedido da ONU. Os dados confirmam que o brasileiro do século vinte um vive oprimido por questões como a violência urbana, o desemprego ou conquista do sucesso profissional. Apesar de ter à disposição um universo de informações antes impensável e recursos para quase todo tipo de situação, o ser humano da atualidade confronta-se com situações psicologicamente ameaçadoras: a insegurança, a competitividade, incerteza com relação ao futuro.

Infelizmente percebemos que essa "onda pessimista" também é um fantasma para muitos ortodontistas. Quem de nós, em algum momento, não se preocupou com o número de profissionais atuando ou com a qualidade dos serviços prestados? Quantos de nossos colegas já manifestaram suas inquietações sobre o andamento de nossa especialidade? Há algumas décadas graduar-se em Odontologia era sinônimo de status e promessa de êxito profissional. Agora, vivemos um período em que é preciso lutar para garantir um lugar ao sol. Mesmo a conquista de uma pós-graduação não é garantia de sucesso profissional, nem tampouco a investida na carreira docente. A solidez da carreira profissional é conquistada pelo contínuo investimento em educação e aprimoramento do atendimento ao paciente - essa é uma afirmação consensual de todos os estudiosos do assunto. Ou seja, o domínio do conhecimento em todos os sentidos (clínico, científico, marketing, relações pessoais etc) certifica um futuro mais promissor.

O desafio gerado pelas dificuldades acaba por estimular o trabalho, e o otimismo deve regê-lo. E esta assimilação pelos profissionais da Ortodontia brasileira vem justificando o destaque apresentado fora do país, o que deve ser considerado como um incentivo aos mais amargurados. No último congresso da $\mathrm{AAO}$, por exemplo, a delegação tupiniquim apresentou 200 trabalhos entre conferências, pôsteres e comunicações orais. Ficamos, em número de trabalhos, apenas atrás dos anfitriões Estados Unidos. Outro dado marcante é a quantidade de artigos que nossos conterrâneos estão publicando no exterior. Quase todas as últimas edições da American Journal apresentaram, no mínimo, um artigo de autoria de brasileiros. Considerando a rigidez das imposições feitas pelo periódico para aceitação de trabalhos, além da natural barreira da língua inglesa, essa conquista é, no mínimo, inspiradora.

Nem é preciso recorrer ao exterior para comprovar como o investimento do ortodontista em conhecimento se traduz em benefício para a especialidade. Nossa publicação é um exemplo nítido disso. A quantidade de trabalhos recebidos marca uma produção cada vez maior em número e em qualidade. Esse volume de artigos, além de corroborar a idéia de que o trabalho é o melhor remédio para o desânimo, serve de parâmetro para que Revista Dental Press promova pequenas alterações na forma de aceitação dos trabalhos, redirecionando-se para um modelo que permita a publicação de um número cada vez maior de artigos.

As observações de nossos editores e colaboradores revelam que os autores brasileiros agem com entusiasmo ao escreverem seus trabalhos, enriquecendo-os com tabelas, detalhes e referências bibliográficas. Essa constatação coopera para elevar o estado de ânimo dos ortodontistas brasileiros, mas contradiz uma tendência mundial na pesquisa científica: a da concentração de informações importantes em um mínimo de espaço possivel. Ou seja, quanto mais sucintos os artigos, mais versatilidade para que a revista consiga publicar uma grande quantidade deles.

Implantando-se um método* que restrinja a quantidade de referências e promova a reunião das idéias em artigos menores, temos certeza de que manteremos o estímulo a apresentação de trabalhos instigantes e com qualidade elevada, privilegiando o leitor. E o que poderia parecer um obstáculo à quantidade de assunto abordado, acabará por conduzir a argüições objetivas, sem detrimento à pesquisa científica.

Com essas e outras adaptações já em curso, a Revista Dental Press espera intensificar ainda mais a pesquisa em nosso país, afastando o desânimo que já é mais claro em outros setores da sociedade. Esperamos que o aprendizado, para quem lê e para quem publica os artigos de nossa revista, estimule carreiras de sucesso e consagração, com entusiasmo e otimismo sempre!

\section{Adilson Luiz Ramos} Editor

\footnotetext{
*maiores informações acesse: www.dentalpress.com.br/normas/pesquisa
} 